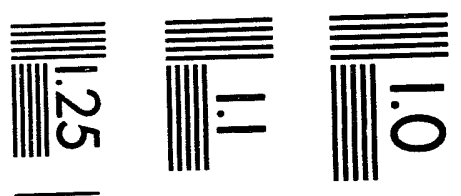

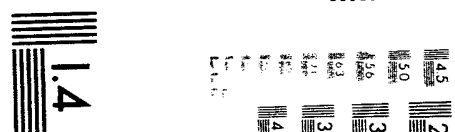

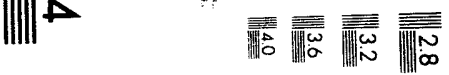

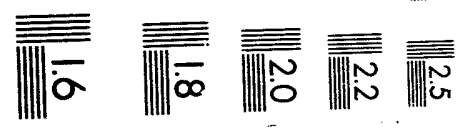



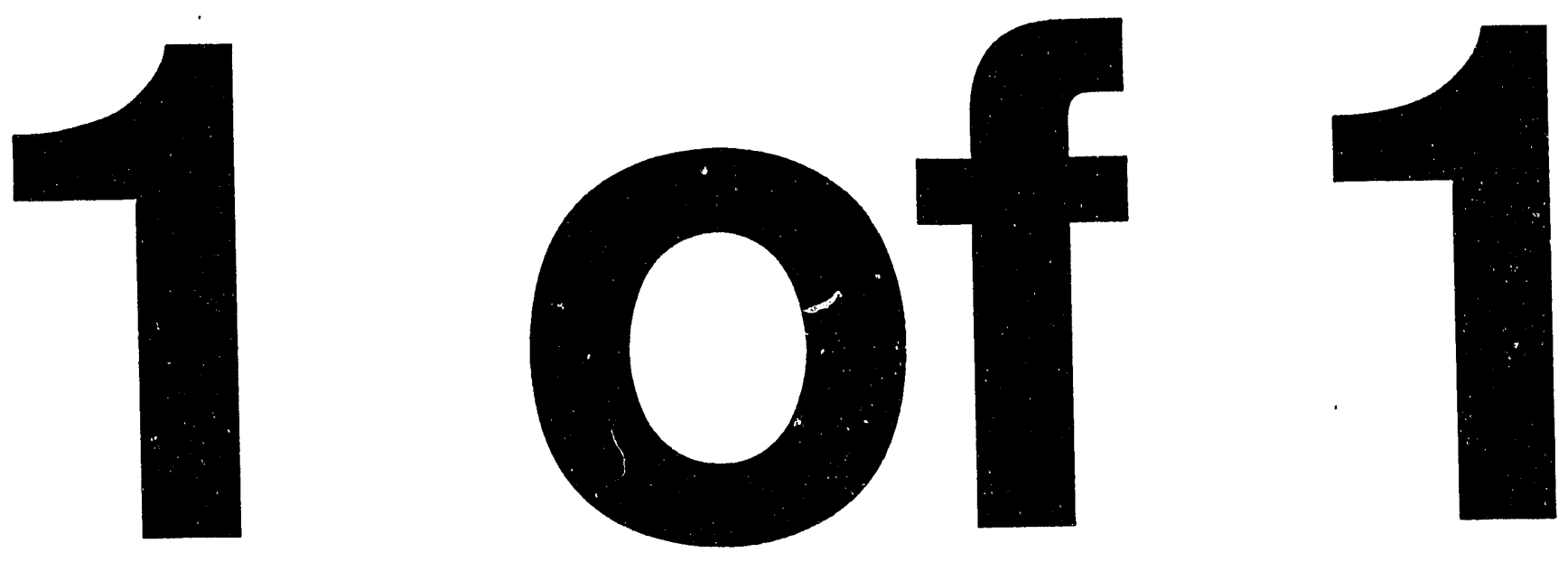


\title{
Regulatory Issues for Waste Isolation Pilot Plant Long-Term Compliance with U.S. Environmental Protection Agency 40 CFR 191B and 268
}

\author{
D. R. Anderson and M. G. Marietta \\ WIPP Performance Assessment Department 6342 \\ Sandia National Laboratories \\ Albuquerque, NM 87119 \\ P. J. Higgins, Jr. \\ Waste Isolation Pilot Plant Project Integration Office \\ United States Department of Energy \\ 1 Park Square, Suite 903 \\ 6501 Americas Parkway NE \\ Albuquerque, NM 87110
}

\begin{abstract}
Before disposing of transuranic radioactive waste at the Waste Isolation Pilot Plant (WIPP), the United States Department of Energy (DOE) must evaluate compliance with long-term regulations of the United States Environmental Protection Agency (EPA), specifically the Environmental Standards for the Management and Disposal of Spent Nuclear Fuel, High-Level and Transuranic Radioactive Wastes (40 CFR 191), and the Land Disposal Restrictions (40 CFR 268) of the Hazardous and Solid Waste Amendments to the Resource Conservation and Recovery Act (RCRA). Sandia Nationa! Laboratories (SNL) is conducting iterative performance assessments (PAs) of the WIPP for the DOE to provide interim guidance while preparing for final compliance evaluations. This paper provides background information on the regulations, describes the SNL WIPP PA Department's approach to developing a defensible technical basis for consistent compliance evaluations, and summarizes the major observations and conclusions drawn from the 1991 and 1992 PAs.
\end{abstract}

$$
\text { rp }
$$

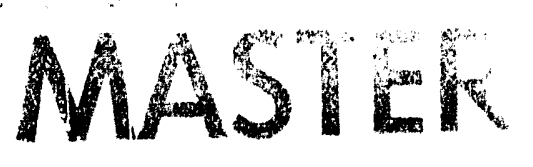




\section{ACKNOWLEDGMENTS}

The authors wish to recognize the technical reviews of this report by David Gallegos and Andrew Peterson (6342) of Sandia National Laboratories. 


\section{PREFACE}

This SAND report is a reproduction of the identically titled paper published in:

American Nuclear Society and American Society of Civil Engineers. High-Level Waste Management:

Proceedings of the Fourth Annual International Conference in Las Vegas, NV, April 26 - 30, 1993. American Nuclear Society, La Grange, IL; American Society of Civil Engineers, New York, NY. 


\section{REGULATORY ISSUES FOR WIPP LONG-TERM COMPLIANCE}

WITH EPA 40 CFR 191B AND 268

D. R. Anderson and M, G. Marietta

WIPP Performance Assessment Department 6342

Sandia National Laboratories

Albuquerque, New Mexico 87185

(505) 8448038

P. J. Higgins, Jr.

Waste Isolation Pilot Plant Project Integration office

United States Department of Energy

1 Park Square, Suite 903

6501 Americas Parkway NE

Albuquerque, New Mexico 87110

(505) 8456347

\section{ABS TRACT}

Before disposing of transuranic radioactive waste at the Waste Isolation Pilot Plant (WIPP), the United States Department of Energy (DOE) must evaluate compliance with long-term regulations of the United States Environmental Protection Agency (EPA), specifically the Environmental Standards for the Management and Disposal of spent Nuclear Fuel, High-Level and Transuranic Radioactive Wastes ( $40 \mathrm{CFR} 191$ ), and the Land Disposal Restrictions (40 CFR 268) of the Hazardous and Solid Waste Amendments to the Resource Conservation and Recovery ACt (RCRA). Sandia National Laboratories (SNL) is conducting iterative performance assessments (PAs) of the WIPP for the DOE to provide interim guidance while preparing for final compliance evaluations. This paper provides background information on the regulations, describes the SNL WIPP PA Department's approach to developing a defensible technical basis for consistent. compliance evaluations, and summarizes the major observations and conclusions drawn from the 1991 and 1992 PAs.

\section{INTRODUCTION}

The United States Department of Energy (DOE) is developing the Waste Isolation Pilot Plant (WIPP), located in 255-million-year-old bedded salt in southeastern New Mexico, for disposal of transuranic wastes generated by defense programs. The DOE must first evaluate compliance with the Environmental Protection Agency's (EPA) Environmental standards for the Management and Disposal of Spent Nuclear Fuel, High-Level and Transuranic Radioactive Wastes (40 CFR 191), 1 and with the Land Disposal

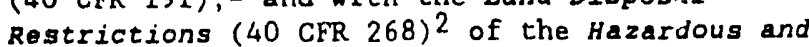
Solid Waste Amendments to the Resource conservation and Recovery ACt (RCRA). The National Environmental Policy ACt (NEPA) ${ }^{3}$ requires all agencies of the federal government to prepare a detailed statement on the environmental impacts of "proposed major federal actions affecting the quality of the human environment." In compliance with the NEPA, an additional supplemental environmental impact statement (SEIS) is planned prior to permanent disposal. 4 Sandia National Laboratories (SNL) is conducting iterative performance assessments (PAs) of the WIPP for the DOE to provide interim guldance while preparing for final compliance evaluations. This paper addresses issues related to developing a defensible and consistent technical basis for evaluating compliance with both 40 CFR 191, Subpart B, and 40 CFR 268.6.

\section{REGULATORY BACKGROUND}

Subpart B of 40 CFR 191 regulates releases of radioactive material to the accessible environment for 10,000 years. As discussed in more detail elsewhere, 5,6,7 the Containment Requirements of 40 CFR $191 \mathrm{~B}$ set limits on the probability that cumulative radionuclide releases to the accessible environment will exceed certain limits. The accessible environment is defined to be " (1) the atmosphere; (2) land surfaces; (3) surface waters; (4) oceans; and (5) all of the lithosphere that is beyond the controlled area $(\$ 191.12[\mathrm{k}]) .1$ The controlled area for the 1992 WIPP PA is the $41 \mathrm{~km}^{2}\left(16 \mathrm{mi}^{2}\right)$ landwithdrawal area.

The Land Disposal Restrictions of the RCRA regulate releases of specified nonradioactive hazardous materials from the repository. For the WIPP, these hazardous materials include heavy metals (HMs) and semivolatile and volatile organic compounds (VOCs). In general, $40 \mathrm{CFR}$ 268 prohibits the disposal of hazardous wastes unless the owner or operator of the facility petitions for a variance and successfully demonstrates, "to a reasonable degree of certainty, that there will be no migration of 
hazardous constituents from the disposal unit or injection zone for as long as the wastes remain hazardous" or the waste is treated in accordance with applicable treatment standards (40 CFR 268.6).2 Guldance provided by the EPA on the interpretation of this wording indicates that "no migration" will be defined to be concentrations of hazardous constituents below health-based or environmentally based levels at the disposal-unit boundary. ${ }^{8}$ The length of the regulatory period will be "a waste- and sitespecific determination," according to EPA guidance, 8 and is assumed by the SNL WIPP PA Department for the purpose of interim analyses to be 10,000 years.

In response to a no-migration variance petition from the DOE, 9 the EPA has issued a conditional no-migration determination 10 allowing the emplacerent of a limited amount of hazardous waste in the WIPP for experimental purposes during the WIPP Test Phase. The EPA states that "[b]efore DOE may move from the test phase to full-scale operations, it must petition EPA again and demonstrate no migration over the long tero- that is, it must successfully address current uncertainties about long-tern WIPP performance" (Ref. 10, p. 47704). Long-term uncertainties specifically identified by the EPA include "the extent and effects of gas generation, the effects of brine inflow into the repository, and the influence of a "disturbed rock zone" surrounding the repository" (ibid.). The Test Phase no-migration determination defines the disposal unit for the WIPP to be the entire volume of the Salado Formation within the WIPP land-withdrawal area, 10

\section{THE ROLE OF PERFORMANCE ASSESSMENT IN COMPLIANCE} EVALUATION

The role of $P A$ in evaluating compliance with 40 CFR $191 \mathrm{~B}$ is described in detail elsewhere. 5,6 Briefly, 40 CFR 191B states that PA shall be used to provide probabilistic estimates of cumulative radionuclide releases, considering uncertainties from "all significant processes and events." 1 The WIPP PA Department uses a Monte Carlo technique and a system of linked computational models to calculate estimates of releases assuming realistic behavior of the disposal system and to display uncertainty in those estimates $5,6,11$

The scope of the performance assessment needed to evaluate compliance of the WIPP (or any transuranic or high-level radioactive waste disposal system) with the long-term requirements of 40 CFR 268.6 has not been established.

Requirements of $40 \mathrm{CFR} 268.6$ are not in all cases consistent with those of 40 CFR 191B, and the SNL WIPP PA Department's approach to resolving potential inconsiscencies would be to (1) assume the same lateral spatial scale for the RCRA disposal-unit boundary as accessible envixonment defined for 40 CFR 191B, (2) assume the same temporal scale for 40 CFR 268.6 as that specifled by 40 CFR 191B, (3) perform a full PA for the chosen RCRA performance measure using the same modeling system applied to undisturbed conditions (no human intrusion) as used for the

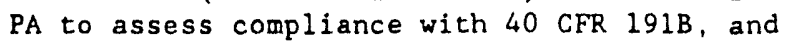
(4) to use these PAs to develop a defensible technical basis for the preparation of a nomigration determination for 40 CFR 268.6 that is consistent with the compliance assessment for 40 CFR 191B.

To date, the WIPP PA Department has used the modeling system and methodology developed for evaluations with respect to 40 CFR $191 \mathrm{~B}$ to conduct preliminary analyses of long-term gas and brine migration from the repository. 12,13 These analyses do not include transport of RCRA contaminants (HMs or VOCs), and are based on preliminary models and data. Results are not sultable for evaluation of compliance with the no-migration requirement of 40 CFR 268.6 .2 Conclusions and observations about the potentiai for RCRA-contaminant migration based on these results are valid only to the extent that ( 1 ) brine migration provides a good diagnostic measure of the potential for migration of HMs and VOCs dissolved in a liquid phase, and (2) gas migration provides a good diagnostic measure of the potential for migration of gas-phase VOCs. Given these assumptions, demonstration that there is a low likelihood that gas or brine will migrate across the disposal-unit boundary in 10,000 years implies a high level of confidence in compliance with the long-term requirements of 40 CFR 268.6. The WIPP PA Department has therefore selected cumulative 10,000-year gas and brine flow across the disposal-unit boundary as a performance measure for preliminary RCRA-related uncertainty and sensitivity analyses to identify important processes and parameters potentially affecting compliance with 40 CFR 268.6 .

Guidance provided by the EPA for determining compliance with $40 \mathrm{CFR} 268.6$ indicates that "[m]odel assumptions and input data should be conservative and tend toward overestimating rather than underestimating migration. " 8 Given present understanding of the physical processes and material properties affecting gas and brine migration, realistic and conservative deterministic calculations cannot be designed at this time. Two-phase fluid flow in the threedimensional repository environment is a complex process that involves nonlinear interactions between multiple, competing processes including humidity-dependent gas-generation reactions, pressure-dependent brine inflow and outflow, pressure-dependent halite creep, and pressuredependent changes in porosity and permeability of the solid phases, including effects of possible fracturing of anhydrite interbeds above and below the waste. Present modeling 
capability and process understanding does not permit including $a 11$ processes in these calculations, and the complexity of the system is such that it is not possible to ldentify in advance combinations of parameter values and assumptions that will result in the largest realistic fluid migrations. The Monte Carlo uncertainty analyses performed to date by the WIPP PA Department, 12 and reported elsewhere in this volume, 13 provide estimates of brine and gas migration based on a range of possible conditions, and therefore provide information about the appropriate level of confidence that should be assigned to performance predictions. Ultimately, this probabilistic methodology can be used to design appropriate conservative calculations using realistic modeling assumptions and combinations of less favorable values selected from realistic ranges for important parameters.

OBSERVATIONS AND CONCLUSIONS FROM THE 1991 AND 1992 WIPP PERFORMANCE ASSESSMENT

All performance assessments for the WIPP to date are preliminary, and results are not suitable for final compliance evaluations. Portions of the modeling system and the data base remain incomplete, and the level of confidence in the performance estimates is not sufficient for defensible compliance evaluations. Results are, however, suitable for providing interim guidance to the WIPP Project as it prepares for final compliance evaluations.

Observations relevant to $40 \mathrm{CFR} 191 \mathrm{~B}$ are based on the third iteration of preliminary WIPP PA, 5,6 completed in 1992 . Observations relevant to 40 CFR 268.6 are based on calculations performed in 1992 using the 1991 PA modeling system.12,13 Additional RCRA-related calculations using the 1992 PA modeling system will be performed during 1993 as part of the 1992 iteration of WIPP PA.

Specific observations and conclusions that can be drawn from the 1991 and 1992 WIPP PAs are as follows:

1. PA analysts have high confidence that compliance with Subpart B of 40 CFR 191 can be demonstrated. Additional work remains before the modeling system and data base can be judged defensible.

2. Based on preliminary analyses, PA analysts have high confidence of demonstrating that HM or VOC tracer concentrations at the disposal-unit boundary will not exceed RCRA Iimits during the 10,000-year regulatory period. Present preliminary analyses indicate that gas is unlikely to migrate laterally to the disposal-unit boundary. Brine, and possible RCRA contaminants contained within it, is unlikely to migrate more than a small fraction of the distance to the lateral boundary or the top of the Salado Formation. If future analyses indicate a higher likelihood of gas or brine from the disposal panels reaching the disposal-unit boundary, engineered modifications to the waste form or repository design may be used to reduce fluld migration. Long-term compliance with $40 \mathrm{CFR} 268.6$, therefore, may not require detailed source-term characterization for calculating concentrations of specific hazardous materials. Heavy metals and other RCRA contaminants transported only by a liquid phase are particularly unlikely to reach the unit boundary.

With regard to long-term compliance with 40 CFR 268, sensitivity analyses indicate that better characterization of certain physical processes and materlal properties within the repositury and the surrounding Salado Formation is essential to a defenstble evaluation of RCRA long-term fluid-migration issues. Specifically. additional information is needed on the parameters affecting gas generation within the waste (gas generation rates for corrosion and microbial reactions under humid and inundated conditions, microbial reaction stoichiometry, and the initial liquid saturation of the waste), and on possible fracturing of anhydrite interbeds above and below the waste in response to elevated gas pressures. Gas generation data will be provided by ongoing and planned laboratory and field experiments with real waste. 14 Pressure-dependent fracturing of anhydrite interbeds will be included in future $P A$ analyses.

PA analyses to date indicate that there is apparently a shaft-seal permeability threshold which can assure that no gas reaches the disposal-unit boundary by flowing up the shafts. 12 The predicted threshold is based on a specific set of model assumptions and should not be interpreted as a design criterion. The predicted existence of such a threshold does, however, provide confidence that a sealing system will prevent vertical gas migration if it can be designed and constructed to achieve that threshold value.

\section{ACKNOWLEDGMENT}

This is Sandia National Laboratories report SAND93-0053C. Work was performed for the United States Department of Energy under Contract DEAC04-76DP00789.

\section{REFERENCES}

1. United States Environmental Protection Agency, "Environmental Standards for the Management and Disposal of Spent Nuclear Fuel, 
High-Level and Transuranic Radioactive Waste: Final Rule, 40 CFR Part 191," Federal Register 50: 38066-38089 (1985).

2. United States Environmental Protection Agency, "Land Disposal Restrictions," Code of Federal Regulations 40, Part 268, Offlce of the Federal Register, National Archives and Records Administration, Washington, D.C. (1986).

3. Public Law 91-190, National Environmental Policy Act of 1969 , as amended by Public Law 94-52 (July 3, 1975) and Public Law $94-83$ (August 9, 1975) (1970).

4. United States Department of Energy, strategy for the Waste Isolation Pilot Plant Test Phase, DOE/EM/48063-2, Office of Waste Operations, US Department of Energy, Washington, D.C. (1991).

5. M.G. Marietta and D.R. Anderson, "Status of WIPP Compliance with EPA CFR 191 B, December 1992," Proceedings of the 1993 International High-Level Waste Management Conference, April 26-30, 1993, Las Vegas, Nevada (1993, this volume).

6. WIPP Performance Assessment Department, Preliminary Performance Assessment for the waste Isolation Pilot Plant, December 1992. Volume 1: Third Comparison with 40 CFR 191, subpart $B$. Volume 2: Technical Basis, SAND92-0700/1,2, Sandia National Laboratories, Albuquerque, NM (1992).

7. Sandia WIPP Project, Preliminary Performance Assessment for the Waste Isolation Pilot Plant, December 1992. Volume 3: Model Parameters, SAND92-0700/3, Sandia National Laboratories, Albuquerque, NM (1992).

8. United States Environmental Protection Agency, "No Migration" Variances to the Hazardous waste Land Disposal Prohibitions: A Guidance Manual for Petitioners, Draft, July 1992, EPA 530/R/92-03, Office of Solid Waste, US Environmental Protection Agency, Washington, D.C. (1992)

9. Westinghouse Electric Corporation, Waste Isolation Pilot Plant No-Migration Variance Petition, DOE/WIPP 89-003, Revision 1. Waste Isolation Division, Westinghouse Electrlc Corporation, Carlsbad, NM (1990).

10. United States Environmental Protection Agency, "Conditional No-Migration Determination for the Department of Energy Waste Isolation Pilot Plant (WIPP), "Federal Register 55: 47700-47721 (1990).
11. J.C. Helton, J.W. Garner, R.P. Rechard, D.K. Rudeen, and P.N. Swift, Preliminary Comparison with 10 CFR Part 191, Subpart $B$ for the Waste Isolation Pilot Plant, December 1991. Volume 4: uncertainty and Sensitivity Analysis Results, SAND91-0893/4, Sandia National Laboratories, Albuquerque, NM (1992).

12. WIPP Performance Assessment Department, Long-Term Gas and Brine Migration at the waste Isolation Pilot Plant: Preliminary Sensitivity Analyses for post-Closure 10 CFR 268 (RCRA), May 1992, SAND92-1933, Sandia National Laboratories, Albuquerque, NM (1992).

13. P. Vaughn, B. Butcher, J. Helton, and P. Swift, Modeling Gas and Brine Migration for Assessing Compliance of the WIPP," Proceedings of the 1993 International High-Level Waste Management Conference, April 26-30, 1993, Las Vegas, Nevada (1993, this volume).

14. United States Department of Energy, WIPP Test Phase Plan: Performance Assessment, DOE/WIPP 89.011, Rev, O, Westinghouse Electric Corporation, Carlsbad, Ni (1990, currently in revision). 


\section{DISTRIBUTION}

(Send Distribution list changes to M.M. Gruebel, Dept. 6342, Sandia National Laboratories, PO Box 5800, Albuquerque, NM 87185-5800)

\section{Federal Agencies}

US Department of Energy (6)

Office of Civilian Radioactive Waste Management

Attn: Deputy Director, RW-2 Associate Director, RW-10/50 Office of Program and Resources Management Office of Contract Business Management

Director, RW-22, Analysis and Verification Division Associate Director, RW- 30 office of Systems and Compliance

Associate Director, RW-40 office of Storage and Transportation

Director, $\mathrm{RW}-4 / 5$ Office of Strategic Planning and International Programs Office of External Relations

Forrestal Building

Washington, DC 20585

US Department of Energy

Albuquerque Operations office

Attn: National Atomic Museum Library P0 Box 5400

Albuquerque, NM 87185

US Department of Energy (2)

Office of Environmental Restoration and Waste Management

Attn: $E M-1$

C. Frank, EM-50

Washington, DC 20585

US Department of Energy ( 3 )

Office of Environmental Restoration and Waste Management

Attn: M. Frei, EM-34, Trevion II

Director, Waste Management Projects

Washington, DC 20585-0002

US Department of Energy

Office of Environmental Restoration and Waste Management

Attn: J. Lytle, EM-30, Trevion II

Washington, DC 20585-0002
US Department of Energy

office of Environmental Restoration and Waste Management

Attn: S. Schneider, EM-342, Trevion II

Washington, DC 20585-0002

US Department of Energy (3)

WIPP Task Force

Attn: G.H. Daly

S. Fucigna

B. Bower

12800 Middlebrook Rd., Suite 400

Germantown, MD 20874

US Department of Energy (4)

office of Environment, Safety and

Health

Attn: R.P. Berube, EH-20

C. Borgstrum, EH-25

R. Pelletier, EH-231

K. Taimi, EH-232

Washington, DC 20585

US Department of Energy (6)

WIPP Project Integration Office

Attn: S. Alcorn

W.J. Arthur III

J. Coffey

L.W. Gage

P.J. Higgins

D.A. Olona

PO Box 5400

Albuquerque, NM 87115-5400

US Department of Energy (2)

WIPP Project Integration Satellite office

Attn: R. Batra

R. Becker

PO Box 3090, Mail Stop 525

Carlsbad, NM 88221-3090

US Department of Energy (10)

WIPP Project Site Office (Carlsbad)

Attn: A. Hunt (4)

V. Daub (4)

$\mathrm{J}$. Lippis

$\mathrm{K}$. Hunter

PO Box 3090

Carlsbad, NM 88221-3090 
US Department of Energy

Research \& Waste Management Division

Attn: Director

PO Box E

Oak Ridge, TN 37831

US Department of Energy (2)

Idaho Operations office

Fuel Processing and Waste

Management Division

785 DOE Place

Idaho Falls, ID 83402

US Department of Energy

Savannah River Operations Office

Defense Waste Processing

Facility Project Office

Attn: W.D. Pearson

PO Box A

Aiken, SC 29802

US Department of Energy (2)

Richland Operations office

Nuclear Fuel Cycle \& Production

Division

Attn: R.E. Gerton

$825 \mathrm{~J}$ adwin Ave.

PO Box 500

Richland, WA 99352

US Department of Energy

Office of Geologic Disposal

Yucca Mountain Project office

Attn: Associate Director, RW-20

PO Box 98608

Las Vegas, NV 89193-8508

US Department of Energy (3)

Nevada Operations Office

Attn: J.R. Boland

D. Livingston

P.K. Fitzsimmons

2753 S. Highland Drive

Las Vegas, NV 89183-8518

US Department of Energy (2)

Technical Information Center

PO Box 62

Oak Ridge, TN 37831

US Department of Energy

Los Alamos Area Office

52835 th Street

Los Alamos, NM 87544
US Department of Energy (2)

Chicago Operations Office

Attn: J.C. Haugen

9800 South Cass Avenue

Argonne, IL 60439

US Department of Energy

Rocky Flats Area office

Attn: W.C. Rask

PO Box 928
G. Huffnian
T. Lukow

Golden, CO 80402-0928

US Department of Energy

Dayton Area Office

Attn: R. Grandfield

PO Box 66

Miamisburg, OH 45343-0066

US Department of Energy

Attn: E. Young

Room E-178

GAO/RCED/GTN

Washington, DC 20545

US Bureau of Land Management

Carlsbad office

101 E. Mermod

Carlsbad, NM 88220

US Bureau of Land Management New Mexico State Office

PO Box 1449

Santa Fe, NM 87507

US Environmental Protection Agency (2)

Radiation Protection Programs

Attn: M. Oge

ANR -460

Washington, DC 20460

US Environmental Protection Agency, Region 6

Attn: C. Byrum, 6T-ET

1445 Ross Ave.

Dallas, TX 75202

US Geological Survey (2)

Water Resources Division

Attn: C. Peters

4501 Indian School NE

Suite 200

Albuquerque, NM 87110 
US Nuclear Regulatory Commission

Division of Waste Managenent

Attn: H. Marson

Mail Stop 4-H-3

Washington, DC 20555

US Nuclear Regulatory Commission (4)

Advisory Committee on Nuclear Waste

Attn: D. Moeller

M.J. Steindler

P.W. Pomeroy

W.J. Hinze

7920 Norfolk Ave.

Bethesda, MD 20814

Defense Nuclear Facilities Safety

Board

Attn: D. Winters

625 Indiana Ave. NW

Suite 700

Washington, DC 20004

Nuclear Waste Technical Keview Board

Attn: Library (2)

1100 Wilson Blvd.

Suite 910

Arlington, VA 22209-2297

Energy and Science Division

Office of Management and Budget

Actn: K. Yuracko

72517 th Street NW

Washington, DC 20503

\section{State Agencies}

New Mexico Bureau of Mines

and Mineral Resources

Socorro, NM 87801

New Mexico Energy, Minerals and

Natural Resources Department

Attn: Librarian

2040 South Pacheco

Santa Fe, NM 87505

New Mexico Energy, Minerals and

Natural Resources Department

New Mexico Radioactive Task Force (2)

(Governor's WIPP Task Force)

Attn: A. Lockwood, Chairman

C. Wentz, Policy Analyst

2040 South Pacheco

Santa Fe, NM 87505
Bob Forrest

Mayor, City of Carlsbad

PO Box 1569

Carlsbad, NM 88221

Carlsbad Department of Development Executive Director

Attn: C. Bernard

PO Box 1090

Carlsbad, NM 88221

New Mexico Environment Department Secretary of the Environment (3)

Attn: J. Espinosa

PO Box 968

1190 St. Francis Drive

Santa Fs, NM 87503-0968

New Mexico Environment Department Attn: P. McCasland

WIPP Project Site Office

PO Box 3090

Carlsbad, NM 88221-3090

New Mexico State Engineer's Office Attn: M. Chudnoff

PO Box 25102

Santa Fe, NM 87504-5102

Environmental Evaluation Group (5)

Attn: R. Neill

7007 Wyoming Blvd. NE, Suite F-2

Albuquerque, NM 87109

\section{Advisory Committee on Nuclear Facility Safety}

John F. Ahearne

Executive Director, Sigma Xi

99 Alexander Drive

Research Triangle Park, NC 27709

James E. Martin

109 Observatory Road

Ann Arbor, MI 48109

\section{WIPP Panel of National Research Council's} Board on Radioactive Waste Management

Charles Fairhurst, Chairman
Department of Civil and
Mineral Engineering
University of Minnesota
500 Pillsbury Dr. SE
Minneapolis, MN 55455-0220 
John O. Blomeke

3833 Sandy Shore Drive

Lenoir City, TN 37771-9803

John D. Bredehoeft.

Western Region Hydrologist

Water Resources Division

US Geclogical Survey (M/S 439)

345 Middlefield Road

Merllo Park, CA 94025

Rodney C. Ewing

Department of Geology

University of New Mexico

Albuquerque, NM 87131

B. John Garrick

PLG, Inc.

4590 MacArthur Blvd.

Suite 400

Newport Beach, CA 92660-2027

Leonard F. Konikow

US Geological Survey

431 National Center

Reston, VA 22092

Jeremiah O'Driscoll

505 Valley Hill Drive

Atlanta, GA 30350

Chris G. Whipple

ICF Kaiser Engineers

1800 Harrison St.

Oakland, CA 94612-3430

National Research Council (3)

Board on Radioactive Waste Management HA 456

Attn: C.A. Anderson

P.B. Myers

G.J. Grube

2101 Constitution Ave. NW

Washington, DC 20418

\section{Performance Assessment Peer Review Panel}

G. Ross Heath

College of Ocean and Fishery

Sciences, HN-15

583 Henderson Hall

University of Washington

Seattle, WA 98195
Thomas H. Pigford

Department of Nuclear Engineering

4159 Etcheverry Hall

University of California

Berkeley, CA 94720

Thomas A. Cotton

JK Research Associates, Inc.

4429 Butterworth Place NW

Washington, DC 20016

Robert J. Budnitz

President, Future Resources

Associates, Inc.

2000 Center Street, Suite 418

Berkeley, CA 94704

C. John Mann

Department of Geology

245 Natural History Bldg.

1301 West Green Street

University of Illinois

Urbana, IL 61801

Frank W. Schwartz

Department of Geology and Mineralogy

The Ohio State University

Scott Hall

1090 Carmack Rd.

Columbus, $\mathrm{OH} \quad 43210$

\section{National Laboratories}

Argonne National Laboratory

Attn: A. Smith

D. Tomasko

9700 South Cass, Bldg. 201

Argonne, IL 60439

Battelle Pacific Northwest

Laboratory (2)

Attn: S. Bates

R.E. Westerman

MSIN P8-44

Battelle Boulevard

Richland, WA 99352

Idaho National Engineering

Laboratory (2)

Attn: H. Loc

R. Klinger

Mail Stop 5108

Idaho Falls, ID 83403-4000 
Los Alamos National Laboratory (5)

Attn: B. Erdal, INC-12

M. Ennis, HS-12

Mail Stop J 900

S. Kosiewicz, EM-7

Mail Stop J595

L. Soholt, EM-13

Mail Stop M992

$\mathrm{J}$. Wenzel, HS-12

PO Box 1663

Mail Stop $\mathrm{K} 482$

Los Alamos, NM 87545

Oak Ridge National Laboratory

Transuranic Waste Manager

Attn: D.W. Turrer

Bldg. 3047

PO Box 2008

Oak Ridge, TN 37831-6060

Pacific Northwest Laboratory

Attn: B. Kennedy

Po Box 999

Richland, WA 99352

Westinghouse-Savannah River

Technology Center (4)

Attn: N. Bibler

J.R. Harbour

M.J. Plodinec

G.G. Wicks

Aiken, SC 29802

\section{Corporations/Members of the Public}

Battelle Memorial Institute

Attn: R. Root

J. Kircher

505 Marquette NW

Suite 1

Albuquerque, NM 87102

Benchmark Environmental Corp.

Attn: C. Frederickson

4501 Indian School NE

Suite 1.05

Albuquerque, NM 87110

Beta Corporation Int.

Attn: E. Bonano

6613 Esther NE

Albuquerque, NM 87109
City of Albuquerque

Public Works Department

Utility Planning Division

Attn: W.K. Summers

PO Box 1293

Albuquerque, NM 87103

Deuel. and Associates, Inc.

Attn: R.W. Prindle

7208 Jefferson NE

Albuquerque, NM 87109

Disposal Safety, Inc.

Attn: B. Ross

1660 L Street NW, Suite 314

Washington, DC 20036

Ecodynamics (2)

Attn: P. Roache

R. Blaine

PO Box 9229

Albuquerque, NM 87119-9229

EG \& G Idaho (3)

1955 Fremont Street

Attn: C. Atwood

C. Hertzler

T.I. Clements

Idaho Falls, ID 83415

Geomatrix

Attn: K. Coppersmith

100 Pine St., Suite 1000

San Francisco, CA 94111

Golder Associates, Inc.

Attn: R. Kossik

4104 148th Avenue NE

Redmond, WA 98052

INTERA, Inc.

Attn: A.M. LaVenue

1650 University Blvd. NE, Suite 300

Albuquerque, NM 87102

INTERA, Inc .

Attn: J.F. Pickens

6850 Austin Center Blvd., Suite 300

Austin, TX 78731

INTERA, Inc.

Attn: W. Stensrud

PO Box 2123

Carlsbad, NM 88221 
INTERA, Inc .

Attn: W. Nelson

101 Convention Center Drive

Suite 540

Las Vegas, NV 89109

IT Corporation (2)

Attn: R.F. McKinney

$\mathrm{J}$. Myers

Regional office

Suite 700

5301 Central Avenue NE

Albuquerque, NM 87108

John Hart and Associates, P.A.

Attn: J.S. Hart

2815 Candelaria Road NW

Albuquerque, NM 87107

John Hart and Associates, P.A.

Attn: K. Lickliter

1009 North Washington

Tacoma, WA 98406

MAC Technical Services Co.

Attn: D.K. Duncan

8418 Zuni Road SE

Suite 200

Albuquerque, NM 87108

Newman and Holtzinger

Attn: C. Mallon

1615 L Street NW

Suite 1000

Washington, DC 20036

RE/SPEC, Inc. (2)

Attn: W. Coons

4775 Indian School NE

Suite 300

Albuquerque, NM 87110

$\mathrm{RE} / \mathrm{SPEC}$, Inc.

Attn: J.L. Ratigan

PO Box 725

Rapid City, SD 57709

Reynolds Electric and Engineering

Company, Inc.

Attn: E.W. Kendall

Building 790

Warehouse Row

PO Box 98521

Las Vegas, NV 89193-8521
Science Applications International

Corporation (SAIC)

Attn: H.R. Pratt

10260 Campus Point Drive

San Diego, CA 92121

Science Applications International

Corporation (2)

Attn: D.C.Royer

C.G. Pflum

101 Convention Center Dr.

Las Vegas, NV 89109

Science Applications International

Corporation (3)

Attn: M. Davis

R. Guzowski

$\mathrm{J}$. Tollison

2109 Air Park Road SE

Albuquerque, NM 87106

Science Applications International

Corporation (2)

Attn: J. Young

D. Lester

18706 North Creek Parkway, Suite 110

Bothe11, WA 98011

Southwest Research Institute

Center for Nuclear Waste Regulatory

Analysis (2)

Attn: P.K. Nair

6220 Culebra Road

San Antonio, TX 78228-0510

Systems, Science, and Software (2)

Attn: E. Peterson

Box 1620

P. Lagus

La Jolla, CA 92038

TASC

Attn: S.G. Oston

55 Walkers Brook Drive

Reading, MA 01867

Tech Reps, Inc. (6)

Attn: J. Chapman (2)

C. Crawford

D. Marchand

T. Peterson

J. Stikar

D. Scott

5000 Marble NE, Suite 222

Albuquerque, NM 87110 
Tolan, Beeson \& Associates

Attn: T.L. Tolan

2320 W. 15th Avenue

Kennewick, WA 99337

TRW Environmental Safety Systems (2)

Attn: I. Sacks, Suite 800

L. Wildman, Suite 1300

2650 Park Tower Drive

Vienna, VA 22180-7306

Sanford Cohen and Associates

Attn: J. Channel1

7101 Carriage Rd NE

Albuquerque, NM 87109

Westinghouse Electric Corporation (5)

Attn: Library

C. Cox

L. Fitch

B.A. Howard

R.F. Kehrman

PO Box 2078

Carlsbad, NM 88221

Westinghouse Hanford Company

Attn: D.E. Wood, MSIN HO-32

PO Box 1970

Richland, WA 99352

Western Water Consultants

Attn: P.A. Rechard

PO Box 4128

Laramie, WY 82071

Western Water Consultants

Attn: D. Fritz

1949 Sugarland Drive \#134

Sheridan, WY 82801-5720

P. Drez

8816 Cherry Hills Road NE

Albuquerque, NM 87111

David Lechel

9600 Allende Rd. NE

Albuquerque, NM 87109

C.A. Marchese

PO Box 21790

Albuquerque, NM 87154

Arend Meijer

3821 Anderson SE

Albuquerque, NM 87108
D.W. Powers

Star Route Box 87

Anthony, TX 79821

Shirley Thieda

PO Box 2109, RR1

Bernalillo, NM 87004

Jack Urich

c/o CARD

144 Harvard SE

Albuquerque, NM 87106

\section{Universities}

University of California

Mechanical, Aerospace, and

Nuclear Engineering Department (2)

Attn: W. Kastenberg

D. Browne

5532 Boelter Hall

Los Angeles, CA 90024

University of California

Engineering and Applied Science Attn: D. Okrent

48-121A Engineering IV

Los Angeles, CA 90024-1597

University of California

Mine Engineering Department

Rock Mechanics Engineering

Attn: N. Cook

Berkeley, CA 94720

University of Hawaii at Hilo

Business Administration

Attn: S. Hora

Hilo, HI 96720-4091

University of New Mexico

Geology Department

Attn: Library

Albuquerque, NM 87131

University of New Mexico

Research Administration

Attn: H. Schreyer

102 Scholes Hall

Albuquerque, NM 87131

University of Wyoming

Department of Civil Engineering

Attn: V.R. Hasfurther

Laramie, WY 82071 
University of Wyoming

Department of Geology

Attn: J.I. Drever

Laramie, WY 82071

University of Wyoming

Department of Mathematics

Attn: R.E. Ewing

Laramie, WY 82071

\section{Libraries}

Thomas Brannigan Library

Attn: D. Dresp

$106 \mathrm{~W}$. Hadley St.

Las Cruces, NM 88001

New Mexico State Library

Attn: N. McCallan

325 Don Gaspar

Santa Fe, NM 87503

New Mexico Tech

Martin Speere Memorial Library

Campus Street

Socorro, NM 87810

New Mexico Junior College

Pannell Library

Attn: R. Hill

Lovington Highway

Hobbs, NM 88240

Carlsbad Municipal Library

WIPP Public Reading Room

Attn: L. Hubbard

$101 \mathrm{~S}$. Halagueno St.

Carlsbad, NM 88220

University of New Mexico

Zimmerman Library

Government Publications Department

Albuquerque, NM 87131

\section{NEA/Performance Assessment Advisory Group (PAAG)}

P. Duerden

ANSTO

Lucas Heights Research Laboratories

Private Mail Bag No. 1

Menai, NSW 2234

AUSTRALIA
Gordon S. Linsley

Division of Nuclear Fuel Cycle and Waste Management

International Atomic Energy Agency PO Box 100

A-1400 Vienna, AUSTRIA

Nicolo Cadelli

Commission of the European

Communities

200, Rue de la Loi

B-1049 Brussels, BELGIUM

R. Heremans

Organisme Nationale des Déchets

Radioactifs et des Matiéres Fissiles (ONDRAF)

Place Madou 1, Boitec 24/25

B-1030 Brusse1s, BELGIUM

J. Marivoet

Centre d'Etudes de 1'Energie

Nucléaire (CEN/SCK)

Boeretang 200

B- 2400 Mo1, BELGIUM

P. Conlon

Waste Management Division

Atomic Energy Control Board (AECB)

PO Box 1046

Ottawa, Ontario KIP 559, CANADA

A.G. Wikjord

Manager, Environmental and Safety

Assessment Branch

Atomic Energy of Canada Limited

Whiteshel1 Research Establishment

Pinewa, Manitoba ROE 1 LO

CANADA

Teollisuuden Voima Oy (TVO) (2)

Attn: Timo Äikäs Jukka-Pekka Salo

Annankatu $42 \mathrm{C}$

SF-00100 Helsinki Suomi

FINLAND

Timo Vieno

Technical Research Centre of Finland (VTT)

Nuclear Energy Laboratory

PO Box 208

SF-02151 Espoo, FINLAND 
Division de la Sécurité et de la Protection de l'Environment (DSPE)

Commissariat á l'Energie Atomique Agence Nationale pour la Gestion des

Déchets Radioactifs (ANDRA)

Attn: Gérald Ouzounian

M. Claude Ringeard

Route du Panorama Robert Schuman

B. P. No. 38

F-92266 Fontenay-aux-Roses Cedex

FRANCE

Claudio Pescatore

Division of Radiation Protection and Waste Management

OECD Nuclear Energy Agency

38, Boulevard Suchet

F-75016 Paris, FRANCE

M. Dominique Greneche

Commissariat á l'Energie Atomique IPSN/DAS/SASICC/SAED

B.P. No. 6

F-92265 Fontenay-aux-Roses Cedex

FRANCE

Robert Fabriol

Bureau de Recherches Géologiques et Miniéres (BRGM)

B.F. 6009

45060 Orléans Cedex 2, FRANCE

P. Bogorinski

Gesellschaft für Reaktorsicherheit (GRS) $\mathrm{MBH}$

Schwertnergasse 1

D-5000 Köln 1, GERMANY

R. Storck

GSF - Institut für Tieflagerung

Theodor-Heuss-Strabe 4

D-3300 Braunschweig, GERMANY

Ferrucio Gera

ISMES S.P.A

Via del Crociferi 44

I-00187 Rome, ITALY

Hiroyuki Umeki

Isolation System Research Program

Radioactive Waste Management Project

Power Reactor and Nuclear Fuel

Development Corporation (PNC)

1-9-13, Akasaka, Minato-ku

Tokyo 107, JAPAN
Tönis Papp

Swedish Nuclear Fuel and Waste

Management Co.

Box 5864

S 10248 Stockholm

SWEDEN

Conny Hägg

Swedish Radiation Protection

Institute (SSI)

Box 60204

S-104 01 Stockholm

SWEDEN

$\mathrm{J}$. Hadermann

Paul Scherrer Institute

Waste Management Programme

$\mathrm{CH}-5232$ Villigen PSI

SWITZERLAND

$\mathrm{J}$. Vigfusson

HSK-Swiss Nuclear Safety Inspectorate

Federal Office of Energy

$\mathrm{CH}-5232$ Villigen-HSK

SWITZERLAND

D.E. Billington

Departmental Manager-Assessment

Studies

Radwaste Disposal R\&D Division

AEA Decommissioning \& Radwaste

Harwe 11 Laboratory, B60

Didcot Oxfordshire OX11 ORA

UNITED KINGDOM

P. Grimwood

Waste Management Unit

BNFL

Sellafield

Seascale, Cumbria CA20 1PG

UNITED KINGDOM

\section{Alan J. Hooper \\ UK Nirex Ltd \\ Curie Avenue \\ Harwe11, Didcot \\ Oxfordshire, OX11 ORH \\ UNITED KINGDOM}

Jerry M. Boak

Yucca Mountain Project Office

US Department of Energy

PO Box 98608

Las Vegas, NV 89193 
Seth M. Coplan (Chairman)

US Nuclear Regulatory Commission

Division of High-Level Waste

Management

Mail Stop 4-H-3

Washington, DC 20555

\section{A.E. Van Luik \\ INTERA/M\&O \\ The Valley Bank Center \\ 101 Convention Center Dr. \\ Las Vegas, NV 89109 \\ NEA/Prohabilistic System Assessment Group (PSAG)}

Shaheed Hossain

Division of Nuclear Fuel Cycle and Waste Management

International Atomic Energy Agency

Wagramerstrasse 5

PO Box 100

A-1400 Vienna, AUSTRIA

Alexander Nies (PSAC Chairman)

Gesellschaft für Strahlen- und

Institut für Tieflagerung

Abteilung für Endlagersicherheit

Theodor-Heuss-Strasse 4

D-3300 Braunschweig

GERMANY

Eduard Hofer

Gesellschaft für Reaktorsicherheit

(GRS) MBH

Forschungsgelände

D-8046 Garching, GERMANY

Andrea Saltelli

Commission of the European

Communities

Joint Resarch Centre of Ispra

I-21020 Ispra (Varese)

ITALY

Alejandro Alonso

Cátedra de Tecnologia Nuclear

E.T.S. de Ingenieros Industriales

José Gutiérrez Abascal, 2

E-28006 Madrid, SPAIN

\section{ENRESA (2)}

Attn: M. A. Cuñado

F. J. Elorza

Calle Emilio Vargas, 7

E-28043 Madrid, SPAIN
Pedro Prado

CIEMAT

Instituto de Tecnologia Nuclear

Avenida Complutense, 22

E-28040 Madrid, SPAIN

Nils A. Kjellbert

Swedish Nuclear Fuel and Waste

Management Company (SKB)

Box 5864

S-102 48 Stockholm, SWEDEN

Björn Cronhjort

Royal Institute of Technology

Automatic Control

S-100 44 Stockholm, SWEDEN

Richard A. Klos

Paul-Scherrer Institute (PSI)

$\mathrm{CH}-5232$ Villingen PSI, SWITZERLAND

Nationale Genossenschaft für die Lagerung Radioaktiver Abfälle (2)

Attn: C. McCombie

F. Van Dorp

Hardstrasse 73

$\mathrm{CH}-5430$ Wettingen, SWITZERLAND

N. A. Chapman

Intera Information Technologies

Park View House

14B Burton Street

Melton Mowbray

Leicestershire LE13 1AE

UNITED KINGDOM

Daniel A. Galson

Galson Sciences Ltd.

35, Market Place

Oakham

Leicestershire LE15 6DT

UNITED KINGDOM

David P. Hodgkinson

Intera Information Technologies

45 Station Road, Chiltern House

Henley-on-Thames

Oxfordshire RG9 1AT

UNITED KINGDOM

Brian G.J. Thompson

Department of the Environment: Her Majesty's Inspectorate of Pollution Room A5.33, Romney House

43 Marsham Street

London SW1P 2PY, UNITED KINGDOM 
Intera Information Technologies

Attn: M.J.Apted

3609 South Wadsworth Blvd.

Denver, CO 80235

US Nuclear Regulatory Commission (2)

Attn: R. Codell

N. Eisenberg

Mail Stop 4-H-3

Washington, DC 20555

Battelle Pacific Northwest

Laboratories

Attn: P.W. Eslinger

MS K2-32

PO Box 999

Richland, WA 99352

Center for Nuclear Waste Regulatory Analys is (CNWRA)

Southwest Research Institute

Attn: B. Sagar

Po Drawer 28510

6220 Culebra Road

San Antonio, TX 78284

\section{Genstatistics Expert Working Group (GXG)}

Rafael L. Bras

R.L. Bras Consulting Engineers

44 Percy Road

Lexington, MA 02173

Jesus Carrera

Universidad Politécnica de Cataluña

E.T.S.I. Caminos

Jordi, Girona 31

E-08034 Barcelona

SPAIN

Gedeon Dagan

Department of Fluid Mechanics and

Heat Transfer

Tel Aviv University

PO Box 39040

Ramat Aviv, Tel Aviv 69978

ISRAEL

Ghislain de Marsily (GXG Chairman)

University Pierre et Marie Curie

Laboratorie de Geologie Applique

4, Place Jussieu

T. 26 - 5 e etage

75252 Paris Cedex 05

FRANCE
Alain Galli

Centre de Geostatistique

Ecole des Mines de Paris

35 Rue St. Honore

77035 Fontainebleau, FRANCE

Christian Ravenne

Geology and Geochemistry Division

Institut Francais du Pétrole

$1 \& 4$, Av. de Bois-Préau B.P. 311

92506 Rueil Malmaison Cedex

FRANCE

Peter Grindrod

INTERA Information Technologies Ltd.

Chiltern House

45 Station Road

Henley-on-Thames

Oxfordshire, RG9 1AT, UNITED KINGDOM

Alan Gutjahr

Department of Mathematics

New Mexico Institute of Mining and

Technology

Socorro, NM 87801

C. Peter Jackson

Harwell Laboratory

Theoretical Studies Department

Radwaste Disposal Division

Bldg. 424.4

Oxfordshire Didcot Oxon OXII ORA

UNITED KINDGOM

Rae Mackay

Department of Civil Engineering

University of Newcastle Upon Tyne

Newcastle Upon Tyne NE1 7RU

UNITED KINGDOM

Steve Gorelick

Department of Applied Earth Sciences

Stanford University

Stanford, CA 94305-2225

Peter Kitanidis

60 Peter Coutts Circle

Stanford, CA 94305

Dennis McLaughlin

Parsons Laboratory

Room 48-209

Department of Civil Engineering

Massachusetts Institute of Technology

Cambridge, MA 02139 
Shlomo P. Neuman

College of Engineering and Mines

Department of Hydrology and Water

Resources

University of Arizona

Tucson, AZ 85721

Yoram Rubin

Department of Civil Engineering

University of California

Berkeley, CA 94720

\section{Foreign Addresses}

Studiecentrum Voor Kernenergie

Centre D'Energie Nucleaire

Attn: A. Bonne

SCK/CEN

Boeretang 200

B-2400 Mol

BELGIUM

Atomic Energy of Canada, Ltd. (3) Whiteshell Research Establishment

Attn: M.E. Stevens

B.W. Goodwin

D. Wushke

Pinewa, Manitoba ROE 1LO, CANADA

Juhani Vira

Teollisuuden Voima oy (TVO)

Annankatu $42 \mathrm{C}$

SF-00100 Helsinki Suomi

FINLAND

Jean-Pierre Olivier

OECD Nuclear Energy Agency (2)

38, Boulevard Suchet

F-75016 Paris

FRANCE

D. Alexandre, Deputy Director

ANDRA

31 Rue de la Federation

75015 Paris

FRANCE

Claude Sombret

Centre D'Etudes Nucleaires

De La Vallee Rhone

CEN/VALRHO

S.D.H.A. B.P. 171

30205 Bagnols-Sur-Ceze, FRANCE
Bundesministerium fur Forschung und Technologie

Postfach 200706

5300 Bonn 2, GERMANY

Bundesanstalt fur Geowissenschaften und Rohstoffe

Attn: M. Langer

Postfach 510153

3000 Hanover 51, GERMANY

Gesellschaft fur Reaktorsicherheit (GRS) (2)

Attn: B. Baltes

W. Muller

Schwertnergasse 1

D-5000 Cologne, GERMANY

Institut fur Tieflagerung (2)

Attn: K. Kuhn

Theodor-Heuss-Strasse 4

D-3300 Braunschweig, GERMANY

Physikalisch-Technische

Bundesanstalt

Attn: P. Brenneke

Postfach 3345

D-3300 Braunschweig, GERMANY

Shingo Tashiro

Japan Atomic Energy Research

Institute

Tokai-Mura, Ibaraki-Ken

319-11, JAPAN

Netherlands Energy Research

Foundation (ECN)

Attn: L.H. Vons

3 Westerduinweg

PO Box 1

1755 ZG Petten, THE NETHERLANDS

Johan Andersson

Swedish Nuclear Power Inspectorate

Statens Kärnkraftinspektion (SKI)

Box 27106

S-102 52 Stockholm, SWEDEN

Fred Karlsson

Svensk Kärnbränsleforsorjning $A B$

Project KBS

Box 5864

S-102 48 Stockholm, SWEDEN 
Nationale Genossenschaft für die

Lagerung Radioaktiver Abfalle (2)

Attn: S. Vomvoris

P. Zuidema

Hardstrasse 73

$\mathrm{CH}-5430$ Wettingen, SWITZERLAND

AEA Technology

Attn: J.H. Rees

D5W/29 Culham Laboratory

Abington

Oxfordshire OX14 3DB, UNITED KINGDOM

AEA Technology

Attn: W.R. Rodwell

044/A31 Winfrith Technical Centre

Dorchester

Dorset DT2 8DH, UNITED KINGDOM

AEA Technology

Attn: J.E. Tinson

B4244 Harwell Laboratory

Didcot, Oxfordshire OXI1 ORA

UNITED KINGDOM

D.R. Knowles

British Nuclear Fuels, plc

Risley, Warrington

Cheshire WA3 6AS, 1002607

UNITED KINGDOM

\section{Internal}

1

20

1502

1511

4511

6000

6115

6115

6119

6119

6121

6121

6233

6300

6302

6303

6303

6305

6305
A. Narath
O.E. Jones
J.C. Cummings
D.K. Gartling
D.P. Garber
D.L. Hartley
P.B. Davies
R.L. Beauheim
E.D. Gorham
Staff (14)
J.R. Tillerson
Staff (7)
J.C. Eichelberger
D.E. Ellis
L.E. Shephard
S.Y. Pickering
W.D. Weart
S.A. Goldstein
A.R. Lappin

6306

6312

6313

6331

6341

6342

6342

6343

6343

6345

6345

6347

6348

6348

6351

6352

6400

6613

6613

6613

6622

6641

7141

7151

$7613-$

8523.2

\author{
A.L. Stevens \\ F.W. Bingham \\ L.S. Costin \\ P.A. Davis \\ Sandia WIPP Central Files (100) \\ D.R. Anderson \\ Staff (30) \\ V. Harper-Slaboszewicz \\ Staff (3) \\ R.C. Lincoln \\ Staff (9) \\ D.R. Schafer \\ J.T. Holmes \\ Staff (4) \\ R.E. Thompson \\ S.E. Sharpton \\ N.R. Ortiz \\ R.M. Cranwell \\ R. L. Iman \\ C. Leigh \\ M.S.Y. Chu \\ R.E. Luna, Acting \\ Technical Library (5) \\ Technical Publications \\ Document Processing for \\ DOE/OSTI (10) \\ Central Technical files
}



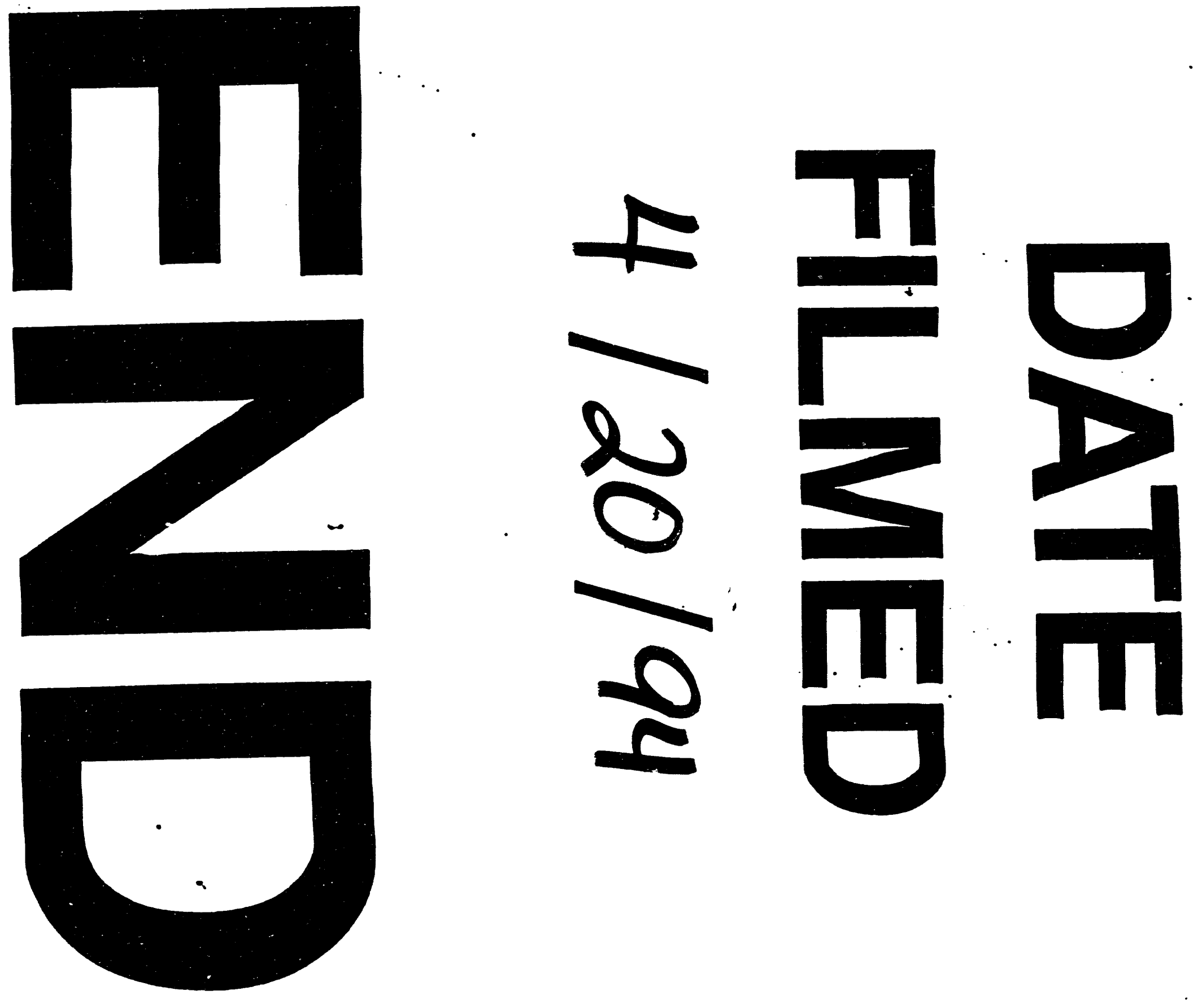


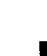

